$\overline{\text { 報文 }}$

\title{
環境満足度之価值観の関連分析 \\ The Related Analysis on the Degree of Environmental \\ Satisfactions and One's Sense of Values
}

\section{SUMMARY}

坂 部 創 一*

The object of this study is to analize the relation of the degree of satistactions for the same environments and one's sense of values. As the order of the analysis, first, each one hundred of husbands and wives were maked investigation into the avove two items. The data, next, were analized by a correlation analysys and a factor analysis. As the rcsults of these analyses, it was found that social environments had more much relation than material environments which had few relation to one's sense of values, and which of desires-reppression-style had few relation to the various degree of environmental satisfactions, or had more less relation, compared with one's sense of desires-satisfaction-style.

$$
<\text { 要 約 }>
$$

本研究の目的は，同一の環境に対する満足度は，主体の価值観と関連があるかどうかを分析することである．万 法は，主人と主婦それぞれ 100 人を対象に環境満足度と価値観の調査を行ない，そのデー夕に相関分析，因子分析を 用いて分析した．その結果，今回の調査対象の場合，価値観との関連が多くみられたのは社会的環境であり物財的 環境とは殆ど関連しないてとが分かったままた，欲求抑制型の価值観は欲求充足型の価値観に比較すると，種々の 環境満足度との関連が殆どないかあるいは低くなる傾向がみられた.

くはじめに>

我々が日常の生活に押いて，同じ環境条件の中にい ても，その環境に対する感じ方は人によって異なると いうことは良く体験するてとである。しかし，てのよ うな事実の要因分析を価值観との関連で計量的に分析 している研究はあまりされていない，本研究では，乙 れを，環境満足度と価值観の関連として分析すること にした.

\section{1. 分析の方法}

本研究における分析の方法は, 図-1のフローのと㧧 りである.

\section{2. 調查の方法と集計結果}

調查は，昭和60年 9 月，筑波研究学園都市の並木住 宅地区の主婦と主人それぞれ 100 人を対象に，留置き法 （調查票を各対象者の所に届け, 後日対象者が記入し
たあのを回収する方法）で行なった，回収率は，主婦 80\%（80人），主人 $60 \%$ （60人）である.

調查の対象地域は, 環境満足度は環境条件によって あ左右されるととを考えて, 住宅や地域の環境条件が 同一の筑波研究学園都市住宅地区の一つである並木を 選択した.

調查項目は，環境に関する20項目，価値観に関する 13項目を設定した. （表 1，表 2）

アンケートの質問形式は，5段階評定法である. (環 境満足度は, かなり不満足, やや不満足, だちらとも いえない，やや満足，かなり満足の 5 段階，価値観は かなりへだたりを感じる，ややへだたりを感じる，ど ちらとむいえない, ややあてはまる，かなりあてはま るの 5 段階の設定である. )

この中の価值観を調查する方法としては，間接法と 直接法が考えられる，間接法とは，日常の生活で行な う種々の具体的な行動（例えば，テレビを良く見る） への適合度を測定し, それを集約再計算して価値観得 


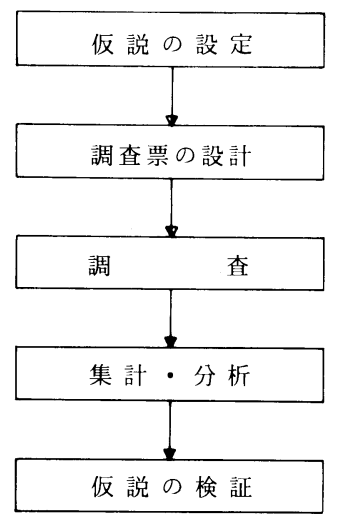

図 - 1 分析のフロー

点を求める方法である. 乙の方法は, 解答しやすいと いう利点があるが，調査項目が多くなり再計算の手順 も複雑になりやすいという久点がある.

直接法とは，価値観の内容を直接的仁記述して，そ れへの適合度を問うという方法である。乙れは, 間接 法に比較すると設問が抽象的になり，ある程度の自己

表 1 環境に関する項目

\begin{tabular}{|c|}
\hline 自然的環境 \\
\hline (1) 家のまわりの自然環境 \\
\hline 社会的環境 \\
\hline （1）保健・医療の施設やサービス \\
\hline （2）住民意志の反映 \\
\hline (3) 安全性 \\
\hline (4) ゴミ収集 \\
\hline (5) 日本の社会保障 \\
\hline (6) 日本の政治 \\
\hline （7）日本の裁判制度 \\
\hline (8) 物 価 \\
\hline 物財的環境 \\
\hline (1) 並木の上下水道 \\
\hline （2）並木の道路（歩道及び車道） \\
\hline (3) あなたの住んでいる住宅 \\
\hline （4）交通機関の便利さ \\
\hline (5) 教育・文化施設 \\
\hline (6) レジャ一施設 \\
\hline （7）買物距離 \\
\hline (8) 商店街品揃え \\
\hline 複合的環境 \\
\hline (1) 住んでいる地域 \\
\hline (2) 静けさ（あなたの住いの周辺） \\
\hline (3) 周辺の景色 \\
\hline
\end{tabular}

表 2 值値観に関する項目

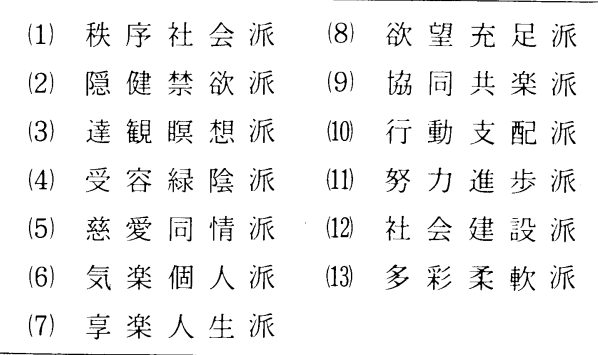

分析が必要となるが, 調査項目が価值観の種類の数だ けで良く，その結果汇複雑な加工計算を行なう必要も ないという利点がある。

本研究に抒いては, 調查対象が研究学園都市の住宅 地区の住人であることを考慮し，直接法を用いるとと にした。

単純集計結果は, 環境満足度に対しては, 主人と主 婦の反応の分布はほぼ同じで, 自然環境, 道路, 地域 環境等が満足度が高く, それに対し, 交通機関, 物価 日本の政治や社会保障等は不満が高くなっている,

価値観に対しては, 主人と主婦の共通点はその時ど きの欲求のおむむくままに思う存分に行動する夕イプ の価值観 (享楽人生派, 気楽個人派, 行動支配派, 欲 望充足派）への適合度の平均値が低いことである. ま た, 多彩柔軟派は両者とも適合度がトップである. 相 違点は, 主人が努力進歩派へ上位の適合度を示すのに 対して，主婦は秩序社会派への適合度が高いととであ る.

\section{3. 環境満足度と価值観の関連}

\section{1 理論仮説}

こてでの理論仮説は，「同一の環境に対する満足度 は，主体の価値観と関連がある」と設定する。

本論では，主体と環境の基本的な関係を図一2のよう に考える，乙れは，主体と環境が，物質・エネルギー

・情報を媒介としながら相互に変換・影響しあう主体 環境系を示している，乙のように，主体は，環境から 常に影響を受けているが，同一の環境条件において異 なった個性が形成・表現されるのは，主体的要因によ るあのと考えられよう. ${ }^{1) 2)}$

(図-3)

ここでは，乙の関係の範囲を限定して，環境満足度 の個人差と価値観の関連を分析してみたい，（図-4） な押，個人的属性として，価值観の他住性別・年令・ 収入等いくつかあげられるが，乙れらは価値観に集約 されているあのとする. 


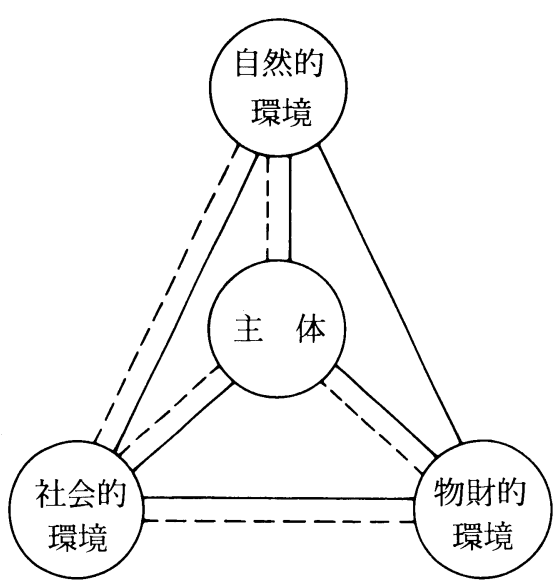

物質・エネルギー

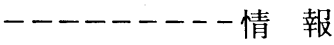

図-2 主体と環境の関係

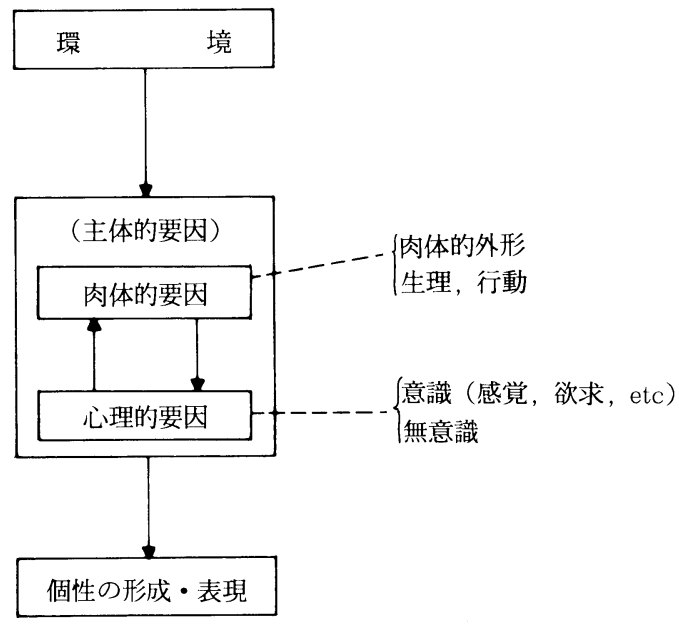

図 - 3 個性の形成亡表現

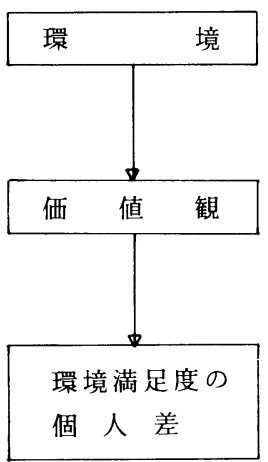

図 -4 環境満足度の個人差

\section{2 作業仮説}

理論仮説を検証するために必要な作業仮説は，次の 二つである.

（1）環境は，自然的環境・社会的環境・物財的環境 に区分し，その他，複合的環境を設定した.

（2）個人の価値観を 12 の価值要因ベクトルの強弱の 程度で表現した。

(1)「環境」という言葉は, 哲学・社会学・心理学 生物学・経済学等々，あらゆる分野で使用され，それ ぞれ各人各様に定義がなされている. 本研究では，環 境とは，「個人又は集団に直接的・間接的に影響を与 える外界」と定義しておく。

環境の分類屯環境の定義と同様，多様性に富んでい るが，乙こでは，基本的に次の三つに区分する.

(1) (自然的環境)

（1)人間生活の立地条件や基盤としての自然その あの.

（2人間生活が改造したり，再生産させた自然

(2) (社会的環境)

〔1〕人間生活が直接又は間接的に接触する集団的 生活保持体系としての社会.

〔2〕情報を通して経験する文化的環境

(3) (物財的環境)

（1)人間生活拡充のために作り出した技術体系と しての物財環境 (道具的環境).

（2〕人間生活の共同保持のために維持している生 活環境施設体系.

〔3]その他, 日常生活で使用する物品 その他として，各環境の複合的環境を設定した.

(2) 価值についてもさまざまな定義がなされている が ${ }^{3)}$; 本研究に打ける価值観の作業仮説的定義は「個人 の生き方において，自分の幸福に重要と考える行動の 価值基準」としておきたい.

こてでの価值観は, 個人のたてまえとしての価值観 （観念的価值観）ではなく，個人の行動原理となって いる本音の価値観（行動的価值観）を意味する.

次に価值観の分類であるが，環境満足度は生活の質 を考えるうえで重要な項目の一つであるので，乙こで は生活の質を意識した価値観の分類法を用いて関連の 構造を分析するてとにした。

既存の研究で，そのような分類を行なっているもの として, 三菱総合研究所のMRI-QOLインデックス ${ }^{4)}$ 今村和男のQOL-BEDインデックス ${ }^{5)}$ ，米国のランド 研究所のQOLファクター等 ${ }^{6)}$ がある. この三つの研究 
は共通点が多いが，相関分析を行なう時サンプルを有 効に使えること, 個人の価値観を視覚的に表現しやす いことを考慮して，今村和男の行なった分類を観念的 価値観から行動的価值観に変形して用いることにした。

\section{(表 3 )}

個人の価値観の表現方法は，三菱総合研究所と同様 な立場に立つ，すなわち，従来の価値観分析手法では 一個人の価値観を一つの主要な価値観に結びつけてい て，ともすると無理矢理に一人の人間の価值観を一つ ときめつけていたようなところがあった. しかし，乙 こでは, 一個人の価値観を 12 種類の価值要因ベクトル の分布によって表現する方式をとる. てのような分布 によって表現できる価值観は，一人一人の「価値観ス ペクトル」とも呼べるであろう.
個人の価値観スペクトルは，ある種の人間では，そ の12種の価值要因に対して非常に强弱の激しいスペク トルを示し，またある種の人間では，12種の価值要因 全部に対して一様に強度を分布させたスペクトルを示 す. (図-5)

後者のようなスペクトルを示す人が，多彩柔軟派上 いう価値観の持ち主ということになる．個人の価值観 スペクトルを 2 次元空間で表示する場合は，その価値 観ベクトルは含まれない，つまり，130ベクトルは必 要でなく，120ベクトルで完全に表現できるのである. ただし，調査票には検証用として13番目の価値観も設 定してある.

価値観の調査結果を因子分析にかけると，表 4, 表 5 のような因子が抽出された.

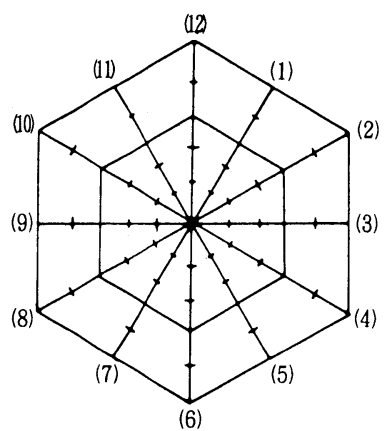

図 - 5 個人の価値観スペクトル

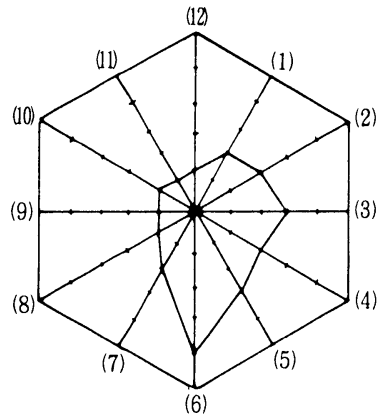

注）これは，今回の調査結果における価値観スペクトルの代表 的な例である。(1)〜(12)の番号は, 表 3 の価值観と対応する。

表 4 価值観の因子（主人）

\begin{tabular}{|c|c|c|c|c|c|c|}
\hline \multirow{3}{*}{$\begin{array}{l}\text { ラ } \\
\text { ソ } \\
\text { キ }\end{array}$} & \multirow{2}{*}{\multicolumn{2}{|c|}{ 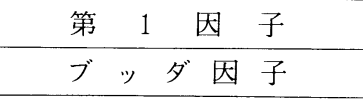 }} & \multirow{2}{*}{\multicolumn{2}{|c|}{$\begin{array}{c}\text { 第 } 2 \text { 因子 } \\
\text { ディオニソス因子 }\end{array}$}} & \multirow{2}{*}{\multicolumn{2}{|c|}{$\begin{array}{c}\text { 第 } 3 \text { 因子 } \\
\text { プロメテウス因子 }\end{array}$}} \\
\hline & & & & & & \\
\hline & \multicolumn{2}{|c|}{$\begin{array}{l}\text { ブ ッ ダ 因 子 } \\
\text { 右 }\end{array}$} & 固 有 值 & $2 \cdot 267$ & \multicolumn{2}{|c|}{ 固 有 值 1.811} \\
\hline \multirow[t]{2}{*}{ グ } & 寄 与 率 & $24 \cdot 11 \%$ & 寄 与 率 & $18.9 \%$ & 寄 与 率 & $15.09 \%$ \\
\hline & 累積寄与率 & $24.11 \%$ & 累積寄与率 & $43.01 \%$ & 累積寄与率 & $58 \cdot 10 \%$ \\
\hline 1 & 達観瞑想派 & 0.82320 & 欲望充足派 & 0.86118 & 努力進歩派 & 0.88952 \\
\hline 2 & 秩序社会派 & 0.74212 & 享楽人生派 & 0.85658 & 社会建設派 & 0.79108 \\
\hline 3 & 隠健禁欲派 & 0.71024 & 気楽個人派 & 0.69859 & 行動支配派 & 0.53477 \\
\hline 4 & 受容緑陰派 & 0.69529 & 行動支配派 & $0 \cdot 39854$ & 協同共楽派 & 0.41366 \\
\hline 5 & 慈愛同情派 & 0.41715 & 達観瞑想派 & $0 \cdot 14873$ & 秩序社会派 & $0 \cdot 24137$ \\
\hline 6 & 気楽個人派 & $0 \cdot 34399$ & 受容緑陰派 & $0 \cdot 13467$ & 慈愛同情派 & 0.20291 \\
\hline 7 & 行動支配派 & $0 \cdot 25360$ & 隠健禁欲派 & $0 \cdot 10368$ & 欲望充足派 & 0.00232 \\
\hline 8 & 協同共楽派 & 0.13057 & 努力進歩派 & 0.02242 & 隠健禁欲派 & -0.00856 \\
\hline 9 & 享楽人生派 & 0.06336 & 慈愛同情派 & -0.01524 & 気楽個人派 & -0.08869 \\
\hline 10 & 努力進歩派 & 0.00165 & 社会建設派 & $-0 \cdot 13234$ & 達観瞑想派 & -0.09836 \\
\hline 11 & 欲望充足派 & -0.14893 & 秩序社会派 & $-0 \cdot 22022$ & 享楽人生派 & $-0 \cdot 11203$ \\
\hline 12 & 社会建設派 & $-0 \cdot 17731$ & 協同共楽派 & -0.23730 & 受容緑陰派 & -0.15486 \\
\hline
\end{tabular}

注）各価值観の右側の数字は，因子負荷量である. (因子負荷量は，因子と変数の相関係数を示す) 
表 3 価値観の種類と内容

（1）【秩序社会派〕私は社会のルールや慣習を大切にし (例，冠婚葬祭・正月・節句・法事・七五三等は型 通り行なう）反体制・反動的なものには批判的であ る. 過度の欲望を避け, 慎しみと知性をむって秩序 ある社会生活を送っている.

(2)〔穏健禁欲派〕私は，自己の内面を見つめつつ社会 生活を送っている. 冒険的な行動や世俗的な欲望は 慎しみ, また隣人への愛とか社会奉仕へものめりこ まない. ひたすら自分の心の平静を保つてとによっ て穏健な社会生活を送っている.

（3）〔達観瞑想派〕私は，自分自身の精神的な充実を重 視して生活している. 社会を変革したり自然を支配 することは望まないし，また欲求のおもむくまま安 楽に暮らすことも望まない. ひたすら自己の修養に 努めて, 悟りの境地を追求する内面的生活を送って いる.

(4)〔受容緑陰派〕私は, 大自然の理法を受け入れて生 きている. 欲望・行動・社会・知性・愛，それらの どれにあとらわれることなく，やすらかに心を開く とき，打のずから体内に満ちてくるものがある. そ れを受け入れることによってやすらかな喜びが得ら れる.

（5）〔慈愛同情派〕私は，他人への思いやりや愛を大切 にして生きている. 人生を豊かにするむのは, 知性 や行動ではなく，共感的な愛である．だから，その ためには，社会を超越することがあってあ良いと思 う. 同情の気持を忘れず, 他を尊重して生きたいと 思っている.

(6)〔気楽個人派〕私は, 気楽な生活を送っている. 自 己の修養・他人との協力・社会の建設・あるいは， 自己の欲望を満たすために努力することなどは好ま ない，多くを望まず，日々の暮らしを気楽に送って いれば，それが扔のずから幸福な人生につながると 思っている.

(7)【享楽人生派〕私は, 人生の楽しみを進んで享受し ている. 人むまた，それぞれ自分の気持ちに従って 楽しめばよい. だから他から規制されることは望ま ないし，他へ要求することもない．社会や他人との かかわりあいを避け, 時として瞑想的に, 時として
感覚的に楽しんでいる.

(8)【欲望充足派〕私は，積極的に人生の楽しみや喜び を追求している. それらは節度ある生活や単なる気 楽な生活, あるいは社会に建設的に参加することか らは得られない，その時どきの欲求のおもむくまま に, 思う存分行動し, 欲望を充足した時に得られる と思っている.

（9）〔協同共楽派〕私は，他の人々と協力して楽しい人 生を送っている. 自己の内面的生活や秩序ある社会 の建設, あるいは個人的な気楽な生活よりあ, 他人 と共に活動し, 共感し, 喜び, 楽しむととを望む. 人々は協同の目的を実現するために協力すべきと思 っている.

(10)〔行動支配派〕私は, 行動的な生活を送っている. 穏健な思想や安楽な生活. あるいは他人への同情な どより勇敢で冒険的な生活がよい，身体的エネルギ 一を用いて積極的に活動することによって障害を圧 倒し, 支配し, 征服する. この中にてそ人生の喜び はある。

(11)〔努力進歩派〕私は，活動的な社会生活を送ってい る. 内面的生活や享楽的な生活は望まない. それよ りは種々の問題の具体的な解決をはかるために努力 し，活動することの方が好きだ．科学や技術を発展 させて社会を進歩させるためにたえず，努力してい る.

(12)〔社会建設派〕私は，建設的な社会生活を送ってい る. 気楽な個人的生活は望まない，厳しい自然や社 会の内にあっても人間の理性を信じて外界を支配し 変革するために努力し，活動している. 理想を保持 し, 合理的な行動をするてとによって人間の気品と 尊㛜が保たれると思う。

(13)【多彩柔軟派〕私は, 柔軟性のある生活を送ってい る. 人生をひとつの目的や価值観や生活様式で貫く ことは，かたよった生き方だと思う．自分自身のう ちに，多様性を養い，時と場合に応じて柔軟な生活 態度がとれることが大切だと思っている. 
表 7 環境満足度と価值観の関連（主人）

\begin{tabular}{|c|c|c|c|}
\hline 境 & 価 值 観 & 相関係数 & 関 連 の 意 味 \\
\hline ・保健 ·医療の施設やサービス & 行動支配派 & 0.42 & $\begin{array}{l}\text { 健康で行動的な人は, 保健 ·医療に対する満足度が } \\
\text { 高い。 }\end{array}$ \\
\hline - 住民意思の反映 & 享楽人生派 & 0.47 & 生活は快適で不満が少ない。 \\
\hline - 安全性 & " & 0.30 & 安全である \\
\hline - 日本の社会保障 & " & 0.29 & 社会保障に対する不満屯少ない。 \\
\hline - 日本の政治 & " & $0 \cdot 38$ & 政治に対する不満屯少ない。 \\
\hline - 物 価 & " & 0.43 & 物価に対する不満屯比較的少ない。 \\
\hline ・交通機関の便利さ & 行動支配派 & $0 \cdot 35$ & 行動のための交通手段を備えている. \\
\hline - 景 色 & 欲望充足派 & -0.29 & 景色への欲求が強い. \\
\hline
\end{tabular}

例えば，主人の住民意志の反映と享楽人生派の関連 をみてみよう，享楽人生派への適合度が高い人は，人 生の楽しみを積極的に享受しているので，生活は快適 で不満が少ない。そのため，地域における住民意志の 反映に対しても相対的に不満が少ないと考える.（正 の相関）

価値観と環境満足度の関連において, 主人之主婦の 相違は, 主人は, 日本の社会保障, 日本の政治等のマ ク口的な環境に関連がみられ，それに対して主婦は， 家のまわりの自然環境，地域等の日常の生活で接する 時間の多い項目に関連がみられる.

それに対して，主婦と主人の共通点としては，次の 三点があげられる. (1)物財的環境より社会的環境の項 目への関連が多いとと. (2)価値観の種類としてブッダ 因子の強い価値観（達観瞑想派, 隠健禁欲派, 受容緑 陰派，秩序社会派）との関連が殆どない（3)主人と主 婦において環境亡価值観の関連が同一のあのは, 保健・ 医療の施設やサービス: 行動支配派, 物価: 享楽人生 派，交通機関の便利さ：行動支配派，周辺の景色：欲 望充足派の 4 項目である.

その理由は，(1)は，価值観は物質的なものよりも文 化に多くその関連が表われやすいてと，(2)は，ブッダ 因子（欲求を抑制する生き方）は, 環境に対する不満 あ少ないが, 欲求充足に伴う喜びあ高くないため, 満 足，不満足どちらにも関連しないと考える.

次に，全体的な特徴を分析するために環境と価值観 の変数で因子分析を行なった. なお，変数として他の 項目の適合度を加算した総合的環境満足度变数を新た に付け加えた.

分析の結果は, 表 8 , 表 9 のようになり, 1 軸は総 合的環境満足度，3 軸は欲求抑制型一欲求充足型と命
名した. この表の因子負荷量をプロットしたのが図-6 である。

ての図から，総合的環境満足度に対しては，欲求抑 制型の価値観の適合度が高い人は欲求充足型との比較 に拈いて，相対的に正の関連が低いことが分かる.

満足度を高め，あるいは不満を少なくするためには， 欲求を充足するか欲求そのものを抑制するという二つ の方法が考えられる. 今回のケースにおいては，満足

表 8 環境と価値観の因子分析（主婦）

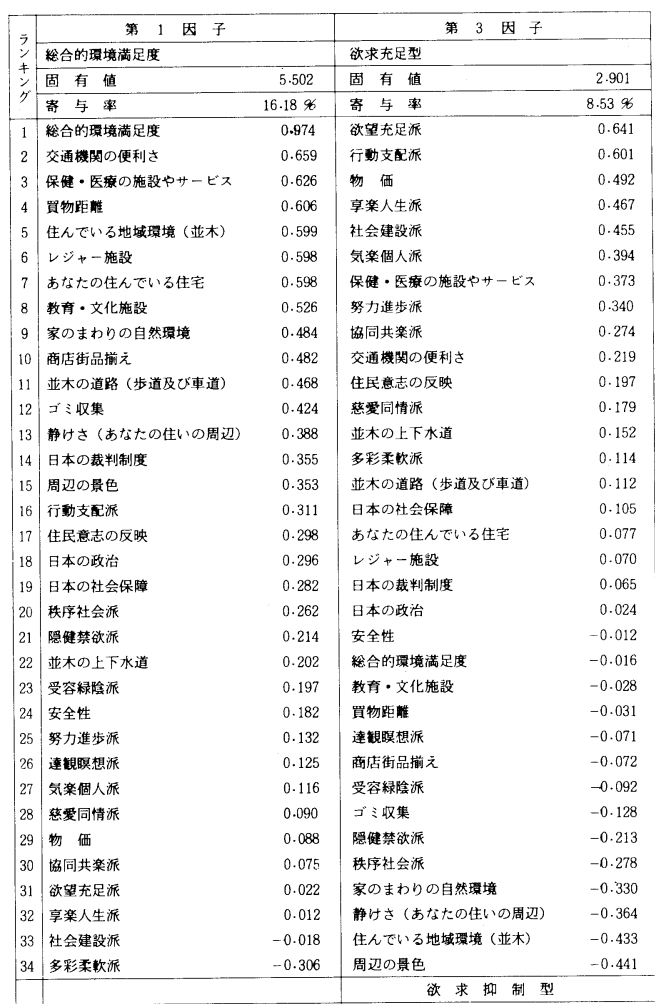


表 5 価値観の因子（主婦）

\begin{tabular}{|c|c|c|c|c|c|c|}
\hline \multirow{3}{*}{$\begin{array}{l}\text { ラ } \\
\text { ン } \\
\text { キ }\end{array}$} & 第 & 因子 & 第 2 & 因子 & 第 3 & 子 \\
\hline & \multicolumn{2}{|c|}{ プロメテウス因子 } & \multicolumn{2}{|c|}{ ディオニソス因子 } & \multicolumn{2}{|c|}{ ブッ ダ 因 子 } \\
\hline & 固 有 值 & $2 \cdot 991$ & 固 有 值 & 2.096 & 固 有 值 & 2.026 \\
\hline \multirow[t]{2}{*}{ グ } & 寄 与 率 & $24.92 \%$ & 寄 与 率 & $17.47 \%$ & 寄 与 率 & $16.88 \%$ \\
\hline & 累積寄与率 & $24.92 \%$ & 累積寄与率 & $42.39 \%$ & 累積寄与率 & $59.27 \%$ \\
\hline 1 & 行動支配派 & 0.82645 & 享楽人生派 & -0.81211 & 達観瞑想派 & 0.76431 \\
\hline 2 & 努力進歩派 & 0.76877 & 欲望充足派 & -0.80469 & 隠健禁欲派 & 0.68892 \\
\hline 3 & 社会建設派 & 0.72120 & 気楽個人派 & -0.70914 & 秩序社会派 & 0.65519 \\
\hline 4 & 協同共楽派 & 0.71530 & 行動支配派 & -0.22344 & 受容緑陰派 & 0.58999 \\
\hline 5 & 慈愛同情派 & 0.50774 & 受容緑陰派 & $-0 \cdot 15384$ & 慈愛同情派 & 0.48512 \\
\hline 6 & 欲望充足派 & $0 \cdot 16861$ & 隠健禁欲派 & -0.11235 & 気楽個人派 & 0.07066 \\
\hline 7 & 受容緑陰派 & $0 \cdot 11010$ & 達観瞑想派 & -0.04751 & 享楽人生派 & 0.04158 \\
\hline 8 & 秩序社会派 & -0.03175 & 慈愛同情派 & -0.03970 & 欲望充足派 & -0.00026 \\
\hline 9 & 達観瞑想派 & -0.07469 & 社会建設派 & -0.01759 & 社会建設派 & -0.00379 \\
\hline 10 & 享楽人生派 & $-0 \cdot 10583$ & 協同共楽派 & 0.19009 & 協同共楽派 & -0.00971 \\
\hline 11 & 気楽個人派 & $-0 \cdot 18428$ & 努力進歩派 & 0.23219 & 行動支配派 & -0.01841 \\
\hline 12 & 隠健禁欲派 & -0.45242 & 秩序社会派 & 0.38792 & 努力進歩派 & $-0 \cdot 18011$ \\
\hline
\end{tabular}

ブッダ因子とは，欲求を規制することによって心の 安らぎを保とうとする欲求, ディオニソス因子とは, その時々の欲求の怙むむくままに思う存分に行動する 欲求, プロメテウス因子とは, 外界を支配し変革する ために活動し努力する欲求である.

これらの因子は, イギリスの心理学者, チャールズ -モリスの三つの「価值の基本的次元」と一致する. あとあと, 本研究で用いた価値観の分析手法は, チャ ールズ・モリスの研究 ${ }^{7)}$ を発展させたものなので, 乙 のような因子が抽出されたことは, 価值観の分類と調
查結果の信頼性が高いことを示している.（表 4.表 5 ）

\section{4 分析結果}

価値観と環境満足度の関連を分析する場合，環境満 足度は客観的水準によっても左右されるので, 分析対 象を同一の環境に限定した. そのため, 収入之余暇, 人間関係，環境全般等の項目は除外している.

両者の関連を分析するため相関係数を求め， $5 \%$ の 検定水準で有意とみなされたもの,また，その中から 疑似相関之思われるあのを除いて表にしたのが表 6 ， 表 7 である.

表 6 環境満足度之価値観の関連（主婦）

\begin{tabular}{|c|c|c|c|}
\hline 環 & 価 值 観 & 相関係数 & 関 連 の 意 味 \\
\hline - 家のまわりの自然環境 & 気楽個人派 & -0.35 & あっと自然に恵まれた所で気楽に暮らしたい. \\
\hline ・保健・医療の施設やサービス & 行動支配派 & 0.30 & $\begin{array}{l}\text { 健康で行動的な人は, 保健・医療に対する満足度が } \\
\text { 高い。 }\end{array}$ \\
\hline - 住民意思の反映 & 気楽個人派 & 0.41 & $\begin{array}{l}\text { 気楽に生活を送っているので, 住民としての不満も } \\
\text { 少ない. }\end{array}$ \\
\hline " & 協同共楽派 & $-0 \cdot 31$ & $\begin{array}{l}\text { 地域の人々と協力して， あっと住民意志の反映を高 } \\
\text { めたい. }\end{array}$ \\
\hline - 日本の裁判制度 & 秩序社会派 & 0.32 & $\begin{array}{l}\text { 社会の秩序維持のための日本の裁判制度には，まあ } \\
\text { 満足している. }\end{array}$ \\
\hline ・物 価 & $\begin{array}{l}\text { 享楽人生派 } \\
\text { 欲望充足派 }\end{array}$ & $\begin{array}{l}0.32 \\
0.28\end{array}$ & 生活は，快適で物価に対する不満も比較的少ない。 \\
\hline ・交通機関の便利さ & 行動支配派 & 0.30 & 行動のための交通手段を備えている. \\
\hline ・住んでいる地域環境（並木） & 欲望充足派 & $-0 \cdot 27$ & より以上の快適な地域環境への欲求が強い。 \\
\hline - 周辺の景色 & " & -0.28 & 景色への欲求が強い. \\
\hline
\end{tabular}


表 9 環境亡価值観の因子分析（主人）

\begin{tabular}{|c|c|c|c|c|}
\hline \multirow{4}{*}{$\begin{array}{l}\bar{y} \\
y \\
\neq \\
y \\
y\end{array}$} & \multicolumn{2}{|l|}{ 第 1 因子 } & \multicolumn{2}{|l|}{ 第 3 因子 } \\
\hline & \multicolumn{2}{|l|}{ 织合的瑔境满足度 } & \multicolumn{2}{|l|}{ 攽求抑制型 } \\
\hline & 固 有 值 & 7.267 & 固有值 & 2.754 \\
\hline & 需与 事 & $21.37 \%$ & 寄与 & $8.1 \%$ \\
\hline 1 & 総合的環境满足度 & 0.973 & 社会派 & 0.756 \\
\hline 2 & 日本の政治 & 0.724 & 㩊揵禁欲派 & 0.611 \\
\hline 3 & 物 価 & 0.607 & 連锤䀧想派 & 0.581 \\
\hline 4 & 家のまわりの自然赖境 & 0.603 & 受容緑䧔派 & 0.486 \\
\hline 5 & 日本の社会保障 & 0.593 & 慧妥同情派 & 0.484 \\
\hline 6 & 保健・医㞠の施設やサービス & 0.584 & 協同其楽派 & 0.334 \\
\hline 7 & 筫物讵離 & 0.575 & 行娌支畆派 & 0.315 \\
\hline 8 & 住んでいる地城瓔境（並木） & 0.570 & 交通機烕の便利き & 0.250 \\
\hline 9 & 交通機関の便利さ & 0.568 & 努力進步派 & 0.199 \\
\hline 10 & 商店街品揃え & 0.540 & 数育・文化施設 & 0.137 \\
\hline 11 & 住民意志の反映 & 0.534 & 買物距矆 & 0.132 \\
\hline 12 & 安全性 & 0.518 & 保健・医瘘の柂設やサーピス & 0.127 \\
\hline 13 & 章楽人生派 & 0.513 & レジャ一施設 & 0.107 \\
\hline 14 & あなたの住んでいる住宅 & 0.511 & 安全性 & 0.102 \\
\hline 15 & レジャ一施設 & 0.495 & 静けさ (あなたの住いの周边) & 0.087 \\
\hline 16 & 教育・文化施設 & 0.473 & 周刃の景色 & 0.073 \\
\hline 17 & 日本の裁判制度 & 0.469 & 商店街品揃え & 0.069 \\
\hline 18 & 並木の道路（步道及び車道） & 0.418 & 気楽個人派 & -0.067 \\
\hline 19 & 行動支海后 & 0.381 & 社会建設派 & -0.021 \\
\hline 20 & 静けさ（あなたの住いの周辺） & 0.380 & 住民意志の反映 & -0.036 \\
\hline 21 & 受容緑䧔派 & 0.361 & 日本の裁判制度 & -0.040 \\
\hline 22 & 並木の上下水道 & 0.341 & 並木の上下水道 & -0.058 \\
\hline 23 & 欲望充足派 & 0.336 & 維合的棵境満足度 & -0.060 \\
\hline 24 & 周辺の景色 & 0.319 & 日本の政治 & -0.095 \\
\hline 25 & 気楽個人脈 & 0.304 & あなたの住んでいる住宅 & -0.107 \\
\hline 26 & 多彩柔饮脈 & 0.304 & 日本の社会保变 & -0.133 \\
\hline 27 & 趡䂓联想派 & 0.287 & $コ ゙$ ミ収集 & -0.183 \\
\hline 28 & 矢序社会派 & 0.216 & 住んでいる地域㺺境（並木） & -0.187 \\
\hline 29 & ゴミ収集 & 0.179 & 亚木の道路 (歩道及び車道) & -0.197 \\
\hline 30 & 社会建設派 & 0.139 & 多彩䅈軟派 & -0.216 \\
\hline 31 & 慈爱同情派 & 0.122 & 享楽人生派 & -0.238 \\
\hline 32 & 努力進歩派 & 0.120 & 欲望充足派 & -0.282 \\
\hline 33 & 嗳煡禁欲派 & 0.012 & 家のまわりの自然謤境 & -0.303 \\
\hline 34 & 協同共楽派 & -0.119 & 物 価 & -0.400 \\
\hline & & & 欲求充足 & \\
\hline
\end{tabular}

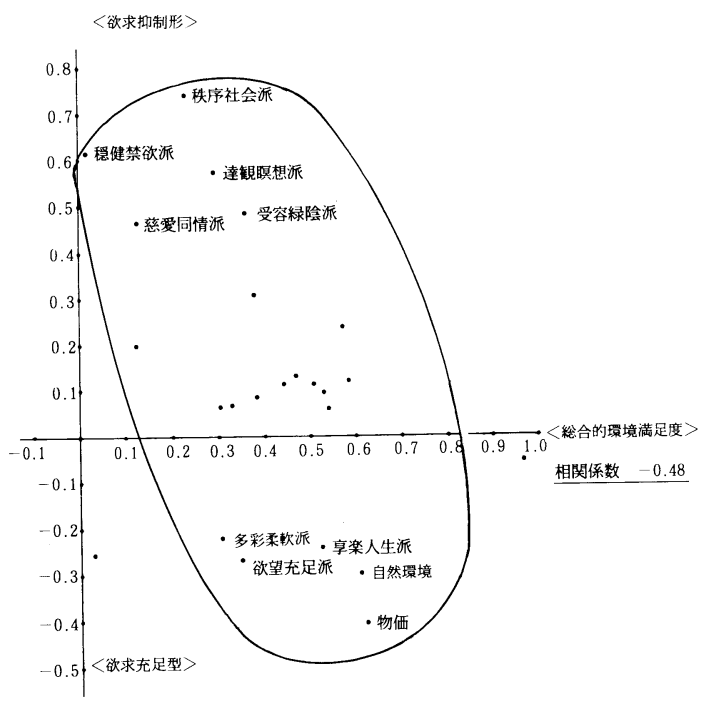

図－6 因子負荷量の関連（主人）
度を高める要因として抑制型よりも充足型の方が相対 的に高い関連を示すととが分かった. 1 軸と 3 軸の相 関係数は，主人が-0.48，主婦は一0.38である.

それ以外の因子間に打いては，関連はみられなかった。

〈おわりに>

環境の調査項目20個のうち，相関係数はそれ程大き くはないが約半数が価值観との関連がみられた. 関連 がない項目の殆どが物財的環境であり，それに対し社 会的環境はほぼ全ての調査項目に関連がみられた。 こ のことから, 今回の調査対象の場合, 価值観は社会的 環境に対する評価への影響力が相対的に強いことが分 かる.

調査における今後の課題としては, 地域や調査対象 による関連の差, 調查する環境項目の種類, そして価 値観の分類之内容があげられる. それは，全ての人間 の価值観を13種類に限定することの限界，また，各価 値観の記述内容の妥当性の問題である。

\section{$<$ 謝 辞 $>$}

本研究を進めるにあたり，調查にご協力頂いた筑波 研究学園都市の並木住宅地区の方々に厚く感謝します. さらに研究に対する指針を示して頂いた筑波大学環境 科学研究科の吉川博也先生に厚く感謝します.

\section{<参考文献 $>$}

(1) Gold,J.R.(1980): An Introduction to Behavioral Geography, Oxford University Press.

(2) Ackoff,R.L. and Emery F.E.(1972): On Purposeful Systems, London, Tavistock Publications.

（3） L.V.ゴードン著,菊地章夫訳(1975)：価值の比較社会心理 学,川島書店

（4）牧野昇編(1976)：環境アセスメントとその手法,三菱総合 研究所,pp.131 149.

（5）今村和男編(1977)：システム分析,日科技連,pp.158 183.

(6) Dallkey, Norman C. (1972): Studies in the Ovality of Life, Rand Corporation.

(7) Morris, Charles (1973): Varieties of Human Value, Bks Demand UMI. 